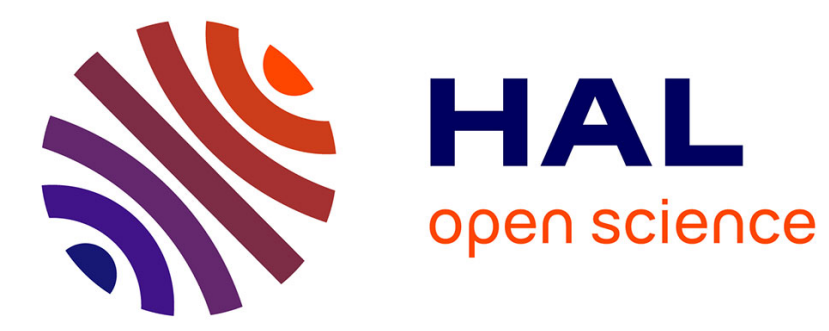

\title{
The Shadow of Heroes: Former Combatants in Post-War Bosnia-Herzegovina
}

Xavier Bougarel

\section{To cite this version:}

Xavier Bougarel. The Shadow of Heroes: Former Combatants in Post-War Bosnia-Herzegovina. International Social Science Journal, 2006, 189, pp.479-490. halshs-00276224

\section{HAL Id: halshs-00276224 \\ https://shs.hal.science/halshs-00276224}

Submitted on 29 Apr 2008

HAL is a multi-disciplinary open access archive for the deposit and dissemination of scientific research documents, whether they are published or not. The documents may come from teaching and research institutions in France or abroad, or from public or private research centers.
L'archive ouverte pluridisciplinaire HAL, est destinée au dépôt et à la diffusion de documents scientifiques de niveau recherche, publiés ou non, émanant des établissements d'enseignement et de recherche français ou étrangers, des laboratoires publics ou privés. 


\begin{abstract}
«The Shadow of Heroes : Former Combatants in Post-War BosniaHerzegovina », International Social Science Journal, n 189, September 2006, pp. 479-490.
\end{abstract}

Xavier BOUGAREL

One of the characteristics of the scientific studies focusing on post-war BosniaHerzegovina is the lack of attention given to former combatants. Yet, after refugees and displaced persons, they represent, one of the most important groups produced by the war. Approximately 2.1 million people, or nearly half of the Bosnian population, were displaced between April 1992 and December 1995, and 400,000 to 500,000 men, nearly two-thirds of all the men of fighting age, were enlisted in the various armed groups (World Bank 2002). ${ }^{1}$ There are several ways to explain this lack of attention to former combatants. On the one hand, the Bosnian conflict is often perceived in terms of moral categories centred on civilian victims, and in reference to an idealised pre-war period in which, by definition, the former combatants did not exist. On the other hand, it is described as one of these "new wars" in which a minority of warlords terrorise unarmed populations and most of those killed are civilians. While it is true that the paramilitary groups did play an essential role at certain times in the war, particularly in "ethnic cleansing" operations, nevertheless, most of the combatants were mobilised by force, and according to recent statistics, $45 \%$ of the 102,000 people who died in the war were soldiers (Tabeau and Bijak, 2005, pp. 187-215).

Understanding the post-war situation involves having better knowledge of what in BosniaHerzegovina is called the "combatant population" (boračka populacija), that is, former combatants, the war disabled, and families of fallen soldiers (Gregson, 2000). ${ }^{2}$ In this article I therefore study the emergence of the combatant population as a distinct social group during and after the war (1992-1995), how its material and symbolic status evolved in the post-war period, its identity crisis from the late 1990s onwards, and the demonstrations that, during the winter of 2001/2002, destabilised the Alliance for Change (Alijansa za promjene), a governmental coalition in power in the Croat-Bosniak Federation. ${ }^{3}$ My analysis is based on various previous works, including the study Bosnia and Herzegovina: Local Level Institutions and Social Capital to which I contributed in 2001-2002 (World Bank 2002).

\title{
Militarism: a forgotten dimension of Yugoslav communism
}

Just as the emergence of the former combatants as a distinct social group has been largely ignored, the role of militarism in the changes in communist Yugoslavia is still generally underestimated. Yet the militaristic nature of Yugoslav communism is certainly not the least significant of its the characteristics (Bašić, 2002; Dimitrijević, 2001). Proclaimed on 29 November 1943, the second Yugoslavia was impregnated by the experience of the Second World War. On the one hand, it derived a great deal of its legitimacy from a founding myth according to which the Yugoslav peoples, united within the "national liberation movement" (narodno-oslobodilački pokret), immediately joined forces to fight against the forces of occupation and political adversaries invariably described as "Quislings" and "the fifth column". On the other hand, the "first-hour combatants" (prvoborci) monopolised the positions of power immediately after the war, and the Communist Party - renamed the League of Communists in 1952 - recruited massively from among the former partisans. Finally, the Union of Associations of Combatants of the Struggle for National Liberation 
(Savez udruženja boraca narodno-oslobodilačkog rata - SUBNOR), founded in 1947, was one of the Party's major mass organisations. As such, it played an important role in the allocation of certain material advantages (such as pensions, public housing and scholarships) and sent its own representatives to the organs of territorial self-government. ${ }^{4}$

In the 1960s new managerial and intellectual elites began to form, whose interests were contrary to those of the political-military elites that emerged from the Second World War. At the same time, the decentralisation process taking place in Yugoslavia was accompanied by the increasing autonomy of the Yugoslav Popular Army (Jugoslovenska narodna armija JNA); some even call it the "seventh republic" of the Yugoslav Federation. Finally, in 1969, a Territorial Defence force (Teritorijalna odbrana - TO) was created in each autonomous republic and province to support the JNA through guerrilla action in the event of foreign invasion. The Territorial Defence, with its basic structures at the level of municipalities and work places, constituted one of the pillars of the Yugoslav doctrine of "general popular defence", along with the JNA, the police, and the civil defence organisation (Milivojević, Allcock and Maurer, 1888; Lukić, 1986). This doctrine manifested not only through the participation of the entire population in various military exercises, but also through new forms of ideological mobilisation based on constant denunciation of foreign aggression and "internal enemies" (Bašić 2002).

The violent break-up of Yugoslavia was partly a result of the crisis in Yugoslav militarism. As economic and political difficulties worsened in the 1980s, the JNA intervened more and more directly in the internal balance of the federation, as shown by its role in repressing the riots in 1981 and 1989-1990 in Kosovo or its alliance with Slobodan Milošević from 1987 onwards (Gow 1992; Hadžić 2004). But the growing involvement of the JNA in the Yugoslav crisis went hand in hand with a loss of legitimacy precipitated by the end of the Cold War and the collapse of communist regimes. In 1991-1992, the independence of Slovenia, Croatia, Macedonia, and Bosnia-Herzegovina was preceded by the gradual departure of non-Serb officers from the JNA, a refusal to transmit orders to mobilise reservists, and an increasing number of demonstrations that were antiwar or anti-army protests (Andjelic 2003). Serbia was also affected by this phenomenon: in the autumn of 1991 mobilisation orders in response to intensified fighting in Croatia led to a desertion rate of nearly 50 per cent and several waves of demonstrations (Useljenicki 1991). When the wars in Yugoslavia began the JNA was largely deprived of the institutional structures and popular support on which it should have leant according to the Yugoslav doctrine of "general popular defence". However, this does not mean that the communist period had no influence on the unfolding of the wars in Yugoslavia, as shown after April 1992 by the ways in which the various armed forces present in BosniaHerzegovina were set up and how their respective combatants were managed.

\section{The material and symbolic status of the combatants: a major issue in the war}

Dozens of armed groups participated in the Bosnian conflict between April 1992 and December 1995, but most of the combatants were incorporated into the Army of the Republic of Bosnia-Herzegovina (Armija Republike Bosne i Hercegovine - ARBiH), the Army of the Serb Republic (Vojska Republike Srpske - VRS), or the Croat Defence Council (Hrvatsko vijeće obrane - HVO), the armed forces of the self-proclaimed "Croat Republic of HercegBosna". The origins of these armies explain some important differences, such as the superiority of the VRS in heavy artillery or the complete dominance of former officers from the JNA, as well as many similarities. The three armies adopted a mode of organisation inspired by the Yugoslav doctrine of "general popular defence", which relied on two main 
types of military units: on the one hand, territorial units with essentially defensive functions, on the other hand, much more mobile elite units. Furthermore, during the war the ARBiH and the HVO experienced a process of professionalisation favouring the return of former officers from the JNA, to the detriment of local commanders linked with the underworld or minority nationalist parties (Bougarel 1996; Gow 2003; Hoare, 2004).

Given the proximity of various combats, the complexity of the frontlines and the moral and material pressures (such as threats of dismissal and confiscation of real estate) exerted on men of fighting age, the desertion rate in Bosnia-Herzegovina was significantly lower than in Serbia. However, troop motivation was a constant concern for the military leaders. In December 1993, Fikret Muslimović, who was in charge of morale at ARBiH headquarters, warned that if "questions dealing with legal, material, social, health, and other issues concerning the protection of combatants, the families of fallen soldiers, and šehids [martyrs], war disabled and wounded" were not better handled, then "there will be even more dissatisfaction among the combatants and their families, the families of šehids and the war disabled, and that will decrease the motivation to fight" (Muslimović 1993: 42).

At about the same time, General Novica Simić, the commander of the Western Bosnia Corps of the VRS, judged that "it is impossible that some people are buying a Mercedes while others don't have enough to eat, because such drastic differences are intolerable during times of war". 5 Likewise, changes in the military balance of power cannot be explained without taking into account the increasing capacity of the ARBiH to move units essentially made up of refugees from one front to another, while at the same time rampant economic crime was threatening the HVO and then the VRS.

To mobilise their combatants, the antagonists were therefore confronted with a dual challenge that was both material and ideological. Materially speaking, they had to take care of the combatants and their families, in a context in which the population had ceased to be predominantly rural, and many urban centres were cut off from their agricultural hinterland and industrial activity had collapsed. Generally speaking, international humanitarian aid compensated for insufficient local agricultural production and played an essential role in setting up a new economy during the war (Andreas 2004; Bougarel 1996). More specifically, various measures were taken in favour of mobilised combatants and their families, sometimes by simply extending the laws already in force for JNA officers or former partisans. First and foremost, these measures included paying pensions for widows and war disabled individuals, upholding of social rights for combatants, and giving them priority access to jobs, housing, and humanitarian aid. Finally, only the HVO had enough financial resources to give a substantial pay to its combatants, through taxes imposed on convoys heading for territories under Bosniak control, and financial support from Croatia and the Croat Diaspora. ${ }^{6}$ As far as the ARBiH and the VRS are concerned, the non-payment of salaries to combatants was offset by the implicit acceptation of hundreds of predatory actions (including pillage of abandoned goods and minor trafficking on the frontline) and the promise of being involved in the future privatisation process. During the war period a largely demonetarised system of social protection thus developed on the ruins of the communist welfare state, at the centre of which were the combatants and their families. ${ }^{7}$

At the same time, the nationalist parties had to replace the ideal of Yugoslav "unity and fraternity" with new grounds for ideological mobilisation. In the first months of the war the war aims of the various protagonists remained poorly defined. The local character of the military units was supposed to reinforce their internal cohesion but it also explains why they 
were reluctant to leave their territory. The fact that these units were mainly funded by municipalities, local public companies and diaspora clubs further exacerbated this reluctance.

Subsequently, the centralisation of war efforts was coupled with an effort towards ideological homogenisation: officers in charge of morale were appointed at every level in the military hierarchy. The reformulation of the discourse on the "internal enemy" and the promotion of new patriotic and religious values were intended to help overcome the old feelings of belonging to a local or Yugoslav community. The armies involved in the Bosnian war thus represent a continuation of and a break with the former JNA, to the extent that they too participated in State-Party systems, but in furtherance of national and ideological projects that were radically different.

This ambivalence can be found in the ways in which the combatants were glorified as heroes and martyrs. The foregrounding of ethnic and religious symbols did not prevent the use of communist vocabulary and did little to conceal strong the ties with the military values inherited from the Communist period (Čolović 2005; Žanić 1998). As Natalija Bašić insists, the combatant identity forged during the 1990s had its origins "in the constitution and selfdefinition of the second Yugoslav state; it was modified during the process of disintegration and according to the national reconstructions at the end of the $20^{\text {th }}$ century, to be turned from a Yugoslav point of view — inwards" (Bašić 2004: 13).

\section{The "combatant population": between interest group and community of experience}

Following the signature of the Dayton Agreement on 14 December 1995, most mobilised combatants were sent back to civilian life and the combined staffs of all the armies involved fell from 400,000 to approximately 100,000 in just a few months. During this same period of time, the combatant population became well defined as a distinct social group. Specific rights instituted during the war were adapted to the circumstances of the post-war period: humanitarian aid gradually stopped playing a decisive role, but the laws on "temporarily abandoned real estate" were extended, the expenditure linked to the payment of pensions for war widows and war disabled individuals was greatly increased, ${ }^{8}$ and privatisation certificates were distributed as compensation for unpaid wages. Furthermore, it was not until after the war that certain commemorative practices linked to the fallen soldiers developed and were used by the nationalist parties symbolically to mark the territories they controlled and to perpetuate their own account of the war.

Another sign of the emergence of the combatant population as a distinct social group is the development of associations representing it. The first associations of former combatants, war disabled or families of fallen soldiers were created in 1993 but they did not play a central role in organising the combatant population until after the end of war. While some, such as the Organisation of Combatants of the Republika Srpska (Boračka organizacija Republike Srpske - BORS) or the Association of Croat Disabled Soldiers of the Patriotic War (Hrvatski vojni invalidi Domovinskog rata - HVIDRA), were immediately controlled by nationalist parties, the situation was more complex in the territories under Bosniak control, in which the Unified Organisation of Veterans (Jedinstvena organizacija boraca - JOB) founded in 1994 was greatly influenced by the Social Democratic Party (Socialdemokratska partija - SDP) and the unions. The Party of Democratic Action (Stranka demokratske akcije - SDA), the main Bosniak nationalist party, encouraged the war disabled and the families of fallen soldiers to leave the JOB in 1995, ${ }^{9}$ and supported the creation of a rival Alliance of Demobilised Soldiers 
(Savez demobilisanih boraca) in 1998. The divisions between the associations representing the combatant population therefore reflect both certain conflicts of interest within this population itself and the main post-war political divisions.

To understand the issues represented by these associations, their situation in the post-war institutional and association landscape must be better understood. The main associations were recognised by the state as official partners. As such, they receive large subsidies and are on the different commissions in charge or establishing the lists of beneficiaries of pensions for disability or widowhood, assessing the degree of disability, or allocating jobs, housing, and the various types of material aid reserved for the combatant population. Therefore, the capacity of these associations to mobilise people is not based on a large number of activists, but on a very dense clientelist network and a high level of synergy with the government and the municipal authorities. In their activities and international functioning, they are reminiscent of the mass organisations of the communist period and resemble other citizens' associations (udruženja građana) created during the war, such as associations of displaced persons, civilian victims or former camp inmates. However, they contrast with the new generation of non-governmental organisations (nevladine organizacije) that appeared after the war with the support of foreign actors, which are most often structured around small groups of activists from urban elites, and whose role in the distribution of international aid is considerable (World Bank 2002). ${ }^{10}$

The para-governmental nature of the associations representing the combatant population appears clearly in the words of Fuad Purišević, the minister in charge of the former ARBiH combatants, who wrote in 2000 :

"a dissatisfied individual, particularly if he belongs to the combatant population and has a low or insufficient standard of living, will not reflect in a rational way, but will simply go along with a chaotic mode of resolving problems. This way of acting is synonymous with destabilising the state and the system under construction. In order to prevent the unfortunate consequences that might result from the disorder that reigns in the activity of the non-governmental organisations of combatants, political and governmental authorities at the highest level must make an urgent commitment to favour their unification. Without the full backing of these authorities we will not be able to succeed in creating such an organisation, which is in the state's interest," (Purišević 2001: 214).

This statement also shows that the feelings of the combatant population do not simply amount to the declarations made by the associations supposed to speak on its behalf, and that the logic that characterises these associations does not always correspond to that of the nationalist parties, contrary to the suggestions of certain studies on post-war BosniaHerzegovina.

While the laws and associations specific to the combatant population have contributed to its emergence as a distinct social group, they do not explain it. In their research on former combatants of the Yugoslav wars, Natalija Bašić and Ivana Maček emphasise their specific experience of danger and violence, and the modes of identification and self-justification that this experience implies. Natalija Bašić emphasises that a

\footnotetext{
"defender identity is the common denominator of the diverse experiences and subjective interpretations produced by the war violence of the 1990s. From the perspective of the people interviewed, the act of defence constitutes not only a stereotyped mode of justification, but also an active and paradoxical process for appropriating [violence]" (Bašić 2002: 284).
} 
The specificity of the combatants experience is relative: Natalija Bašic emphasises the diversity of individual trajectories and discourses while Ivana Maček recalls that, in besieged Sarajevo, combatants and civilians were largely confronted with the same dangers, the same material difficulties, and the same moral dilemmas (Maček 2005: 57-76). But the combatants and their families nevertheless constitute a distinct community with a common experience, as shown by their frequent hostility towards those who escaped from mobilisation or took refuge in a foreign country.

As well as its material and symbolic status, this shared experience of war enables the combatant population to influence changes in post-war society. As they are part of the adult male population, but also because of their authority they acquire in society and the solidarity forged among them during the war, ex-officers and former combatants are also overrepresented in various types of associations ranging from neighbourhood councils to sports clubs and associations of displaced persons and unions (World Bank 2002: 114). The emergence of the combatant population as a distinct social group cannot therefore be understood without taking into account the specific experiences of violence underlying it, the material and symbolic status it enjoys in the post-war period, and the associative and clientelist networks in which it is integrated.

On the other hand, this population should not be considered as a homogeneous entity or cut off from the rest of society: the rifts stemming from the war are numerous and shifting and, in addition, interact with those that preceded the war rather than replacing them. The war has not only reconstructed gender identities, but also blurred certain pre-war categories (Helms 2003: 181-198). Displaced persons of rural origins, who are over-represented in the combatant population, demand access to urban amenities. This is contested by the former urban elites (Stefansson, 2004: 54-75).

The workers, impoverished by a decade of war and unemployment, reconstitute their class identity around a discourse of the struggle to survive. In October 1998, in the industrial city of Zenica, organisations of former combatants, steelworkers unions, and miners demonstrated under the banner "Gospodini, još smo živi!" ("Gentlemen, we are still alive!") (Office of the High Representative, 1998). Five years later, during a hunger strike, coal miners declared that the World Bank had sacrificed them, like the UN during the war. The monument dedicated to the fallen soldiers erected inside the mine by the local section of the JOB bears the following inscription, attributed to the sixteenth-century writer Hasan-kafi Pruščak: "People, be vigilant! Nation, wake up! Everyone be vigilant! You are under the gaze of God. Tomorrow you will have to explain yourself: do not argue for positions [of power], and do not overlook the blood of our $\breve{s}$ hids without showing concern for it". ${ }^{11}$ In this precise case, the combatants' identity and the workers' identity come together to denounce the incompetent and inhuman elite leaders. The reconstruction of the social identities brought about by the war is no less striking: let us remember that, in the months preceding the war, the slogan of the steelworkers and miners unions that participated in the pacifistic demonstrations was "Radnici, a ne ratnici!" ("Workers not warriors!").

\section{The identity crisis of the combatant population}

At the end of the 1990s, the privileges enjoyed by the combatant population proved to be largely illusory. Because of the gap between legal provisions and available funds and resources, there were more and more delays in payments of various military pensions. In 
addition, under pressure from international financial institutions, the Croat-Bosniak Federation and the Republika Srpska agreed in December 1998 to reduce their armed forces from 100,000 to 34,000 soldiers $^{12}$ and in July 2000 the government of the Federation opened painful negotiations on the criteria for the allocation of disability and widowhood pensions. Finally, the relative decline in the material well-being of the combatant population is symbolised by the fact that the privatisation certificates distributed to the former combatants lost 97 per cent of their value in a few years and that, following the modification of the laws on "temporarily abandoned real estate" by the High Representative Carlos Westendorp, many families of combatants were evicted from lodgings they had obtained during the war and sometimes had to return to the collective housing centres opened at the same time (Philpott, 2005).

At the same time, the political-criminal elites that emerged from the war were flaunting their wealth and many refugees returning to Bosnia-Herzegovina became part of the local staff of international organisations thanks to their linguistic skills, or participated in smallscale privatisation thanks to the financial assistance they had received upon their return. The former combatants no longer appeared to be heroes, but as naive losers, in contrast to those who were able to gain an advantage from the war or at least to escape from it.

This loss of prestige among the former combatants is also the consequence of the political context of the period. By 1998 the increasing involvement of international organisations in internal changes in Bosnia-Herzegovina resulted in a growing number of arrests of officers indicted by the International Criminal Tribunal for the former Yugoslavia (ICTY), in a partial lustration of the security forces, and in increased control over the content of the national electronic media and educational programmes. Together with the growth of independent media outlets, the hardening position of the international community destabilised official accounts of the war and, indirectly, the heroic image of the combatants. The decline in the material and symbolic status of the combatant population, coupled with their high rate of unemployment, led to a veritable identity crisis, as attested by the interviews carried out in the spring of 2001:

"During the war I could go into [city hall] with a gun, stamp my feet and say that my child had no bread to eat. There was flour and oil for the combatants, we could find anything. That all lasted as long as the war continued. Even after the war was over, and until about two years ago, we could still make things happen, we were somebody, at least those in power were afraid because they knew that they had been elected thanks to us. But now we are no longer useful to anyone." (Former combatant of the VRS, Zvornik) (World Bank 2002: 36).

"Now I'm simply ashamed of having worn this uniform and having been part of this army. It's because once the war had finished, when I went to look for some help, I had eight children in school, I went to talk to the mayor, my daughter and my son were very good students and I wanted them to continue their studies, and I asked for exceptional assistance. But it's not easy to meet the mayor, you have to make an appointment, take a yellow ticket. As demobilised combatants we didn't received anything. I was ashamed and I'm still ashamed of having worn this uniform." (Former combatant of the ARBiH, Tuzla) (World Bank 2002: 36).

Idealised during the war as defenders of their families and their people, the former combatants feel abandoned by the state, looked down on by society, and incapable of fulfilling the needs of their families. The feelings of injustice and bitterness were very common among the combatant population and, at the end of the 1990s, there were more and more demonstrations with people demanding the payment of overdue military pensions or an 
end to the evictions of the war disabled and war widows. In this context, the former combatants contrasted the legitimacy they acquired during the war with that of the local and international institutions, as illustrated by this statement by the informal leader of displaced persons in the Mihatovići collective housing centre in a suburb of Tuzla :

"I am the most aggressive, I can't stand injustice and I feel free enough to say it to people. Two and a half years ago I spoke with [President] Izetbegović. I told him: 'Old man [dedo], why are you doing such crazy things, some people have stolen all the money, and you know very well that nobody besides your son could buy the new windows for this centre.' I explained how and all that. Then he said to me: 'You, with your high school diploma, you're trying to give me a lesson, and it's me who has a law degree?' and I said: 'Old man, these four years of war have been my university and I studied law, astronomy and this and that, these years taught me everything."” (World Bank 2002: 115).

The rancour of the former combatants can also be expressed in the form of individual violence, as demonstrated by the rising number of suicide attempts, domestic violence, and aggressive behaviour towards administrative staff. A former combatant from Zvornik relates that at the municipal medical centre:

"it is written in a notice on the door that children are not charged, but this is not the truth. Both of my children have problems with bronchitis and I have to go there quite often and I have to pay for everything - it even happened to me once that they said they would not take in my child because I did not have the money to pay. However, when I took out my gun, and I had to take it out, then they took my child in." (World Bank 2002: 71).

Finally, the former combatants express a strong desire to emigrate, which can even lead to certain unexpected forms of collective action, as when, for example, 450 war disabled from the enclave of Srebrenica requested in December 1998 permission to emigrate collectively to the Netherlands (Hadžić 1999).

\section{The Alliance for Change and the 2002 demonstrations}

The identity crisis in the combatant population helps explain why there was a record rate of abstention (35 percent) in the November 2000 general elections and why the SDP made significant progress to the detriment of the SDA. The SDP then formed the Alliance for Change (Alijansa za promjenu), a governmental coalition that replaced the traditional SDACroat Democratic Community (HDZ) coalition in the Federation. However, as soon as it was in a position of power, the Alliance was in turn confronted with the difficult question of the former combatants.

The first illustration of this reality was the "Croat crisis" that broke out following the modification of the electoral law by the Organisation for Security and Cooperation in Europe (OSCE) and the subsequent loss by the HDZ of its blocking power within the Federation (International Crisis Group, 2001). The HDZ held a referendum in favour of the creation of a third Croat entity and called on all Croat state employees - including soldiers and police officers - to leave the federal institutions. This initiative by the HDZ was supported by the organisations representing the Croat combatant population and, between January and April 2001, the former combatants, the war disabled and the war widows of the HVO took part in numerous hostile demonstrations against the international community. At a time when Croatia was also experiencing a political changeover and decided to decrease its subsidies to the Croat "Herceg-Bosna", the fact that the HDZ was no longer participating in the governmental 
coalition of the Federation was a direct threat to the material interests of the Croat combatant population. The confrontation between the $\mathrm{HDZ}$ and the international community, carried out in the name of the "survival of the Croat people", also had to do with more specific statutory issues, and it was by taking direct action with respect to the Hercegovačka banka, the bank through which the pensions paid to the combatant population was transferred, that the High Representative Wolfgang Petritsch was able to put an end to the "Croat crisis" in April 2001.

In our framework, however, the most significant crisis is the one that took place after the attempt to reform the disability and widowhood pensions. To understand the context of this crisis we must remember that the discussions on reforming military pensions were opened before the November 2000 elections. At that time Fuad Purišević wrote that the new legislation

"must be realistic and based on the objective capacities of the State, because this will enable the rights thereby established to be continuously and regularly respected. If, on the contrary, the legislation does not lead to an effective implementation of the rights, this will represent a constant source of social unrest, which in the end will be impossible to avoid" (Purišević 2000: 94).

The bill negotiated in 2001 by the World Bank, the government of the Federation, and the associations representing the combatant population therefore envisages stricter criteria for allocating disability and widowhood pensions, linking them to the revenues already available to the war disabled or the families of fallen soldiers, and a stricter control over the list of beneficiaries. Such a project was intended to enable both a decrease in the expenditure linked to the combatant population and an increase in pensions paid to its most vulnerable members, such as the totally disabled or jobless war widows. However, when it was presented to the Parliament of the Federation in the autumn of 2001, it quickly led to the hostility of the associations representing the combatant population and there were major demonstrations.

There is little doubt of the SDA's desire to use the debate on the reform of disability and widowhood pensions to get revenge on the SDP. Once again, however, this political dimension does not explain everything, and one must also consider the demonstrations in the winter of 2001/2002 as a sign of an identity crisis that had only worsened since the Alliance came to power. In the early $2000 \mathrm{~s}$, the increasingly vehement discourses on the threat of terrorism in Bosnia-Herzegovina, the indictment of several generals from the ARBiH by the ICTY and the return of military apartments to former officers of the JNA exacerbated the rancour of many former combatants. The reform of military pensions was itself perceived to be profoundly unjust, not only because it deprived many war disabled and families of fallen soldiers of an important source of income, but also because it replaced a logic of meritocracy - sacrifices made during the war - by a redistributive logic - material needs in the postwar period - and thereby hastened the loss of prestige of the combatant population.

This impact of the reform on the symbolic hierarchies inherited from the war is further reinforced by the fact that the word "šehid" did not figure in the wording of the bill, and that the bill was presented by Suada Hadžović, the new minister in charge of the combatant population. Many former combatants regarded the appointment of a woman to this post while at the same time the first commander in chief of the ARBiH, Sefer Halilović, occupied the post of Minister of Social Affairs - as an additional sign of their devalorisation and their "demasculinisation". The adversaries of the Alliance often played on these symbolic dimensions of the crisis, and while the Reis-ul-Ulema Mustafa Ceric claimed that the government "attacks our faith and our honour" (Cerić 2002), the journal "Ljiljan" "The Lily", close to the SDA) accused Suada Hadžović of wanting to "settle her scores with the 
šehids" and being more preoccupied by the naked women's bodies displayed on the billboards of Sarajevo than the mutilated bodies of disabled ex-servicemen thrown out onto the streets (Omeragić 2001). The crisis came to a head when, on 1 March 2002, several thousand former combatants from the ARBiH demonstrated in Sarajevo and certain of them physically attacked Zlatko Lagumdžija, president of the SDP and Prime Minister of the Federation. The following day, he likened the demonstrators to the Serb hooligans by whom he had been confronted a year earlier in Banja Luka, in the Republika Srpska. This was followed by a very violent controversy: the SDA demanded that Lagumdžija should apologise for having "compared the legitimate discontent of the defenders of Bosnia-Herzegovina with the orgy of violence in which the Chetniks [Serbian nationalists] indulged during the inauguration ceremony of the reconstruction of the Ferhadija mosque", ${ }^{13}$ and he retorted that it was up to the SDA to "apologise to those to whom it had lied for years, having plunged them into despair and misery." ${ }^{14}$ The bill, however, was largely modified in the following months, and adopted just before the November 2002 elections, which resulted in the return to power of the SDA-HDZ coalition in the Federation.

\section{Conclusion: is the combatant population an obstacle to peace?}

The links between the associations representing the combatant population and the nationalist parties, and the central place this population occupies in the demonstrations hostile to the ICTY and to the international community, often lead outside observers to present it as an obstacle to peace in Bosnia-Herzegovina. These analyses, however, are overly simplistic for two reasons. First of all, they only take into account the forms of action and collective organisation in which the combatant population appears in that capacity, and not those in which the former combatants, the war disabled or the relatives of fallen soldiers make use of the status inherited from the war in other contexts and to other ends. However, it turns out that former combatants and their associations sometimes play an important role in certain interethnic mediations. For example, Paul Stubbs shows how, in Travnik, the participation of the associations of former combatants in "minority reintegration" programmes has facilitated the management of the conflicts that accompany them (Stubbs 1999). A similar situation can be found in Klanac, on the outskirts of Brčko, in which the leader of the Serb displaced persons who settled there at the end of the war used his experience as an officer to help people make compromises (World Bank 2002: 29-30). Furthermore, these analyses do not study the way in which combatant identity, or rather combatant identities, are related to other social identities dating back from before the war or having emerged in the post-war context. Yet, it is only by taking into account these different aspects that is becomes possible to examine the role played by the former combatants in post-war Bosnian society, and the role they may be able to play in it one day ${ }^{15}$ Likewise, it is on this basis that one should consider the political limits of the Disarmament, Demobilization and Reintegration (DDR) programs, centred as they are either on the professional retraining of demobilised combatants, or on treating their psychological disorders (Heinemann-Grüder et al. 2003). Such programmes largely ignore the specific memories and representations of this category of the population. The way in which the reform of the military pensions was handled in $2001 / 2002$, both by the international community and the Alliance for Change, illustrates this problem well. 


\section{Notes}

1. I have no statistical data on the number of women who participated in these armed forces. In the opinion poll completed within the framework of the study Bosnia and Herzegovina: Local Level Institutions and Social Capital, 53.8 per cent of the men and 8.0 per cent of the women interviewed said they had the status of former combatants, but it is probable that some of them were in fact widows or mothers of fallen soldiers.

2. In 1999 , according to data from the World Bank, there were approximately 85,000 war disabled and 110,000 families of fallen soldiers in Bosnia-Herzegovina.

3. Since the signature of the Dayton Agreement, Bosnia-Herzegovina is made up of two entities: the Federation, itself sub-divided into ten ethnic cantons, and the Republika Srpska.

4. On the role of the SUBNOR in communist Yugoslavia, see Remington 1978:181-189.

5. Stit, mouthpiece of the Western Bosnia Corps of the VRS (January 1994), cited in Borba (11 March 1994).

6. The officers of the VRS continued to be paid by the Federal Republic of Yugoslavia (SerbiaMontenegro), but this was not the case for ordinary combatants.

7. This does not mean that the combatant population is living in an enviable material situation. For instance, in its March 1995 newsletter, the Association of Families of Šehids of Sarajevo recalls that during the winter of 1993/1994, it asked the municipal authorities to provide each family with 2 litres of milk per week, as well as 2 to 3 kilos of pasta and 5 to 10 kilos of flour per month, and that is protested several times against cuts in the distribution of cigarettes - the "only means of payment for the majority of us" - and against the "attribution of uninhabitable apartments, which had been bombed, pillaged, and ransacked". The association raised the following question: "Almost every day the newspapers announce that certain institutions focus solely on the families of those killed, but we do not see any results anywhere. We wonder how these long lists of children of šehids are being used, these photos of entire generations. Who are these people that are using our children? Where are the donations that are given in their name, in the name of the families of sehids?" (Udruženje porodica šehida "Sas-Bos", Informativni bilten, March 1995, pp. 6, 8 and 9).

8. In the Federation, they rose from $16,000,000$ convertible marks (approximately 8,000,000 euros) in 1995 to $100,000,000 \mathrm{KM}$ in 1996 and 204,000,000 KM in 1998 (Purišević 2000: 83).

9. The war disabled are united within the Alliance of war disabled (Savez ratnih vojnih invalida) and the families of fallen soldiers within the Organisation of families of šehids and fallen soldiers (Organizacija porodica šehida i poginulih boraca). A similar division can be found within the Croat combatant population, for which there are three distinct associations: the Association of Volunteers and Veterans of the Patriotic War (Udruga dragovoljaca $i$ veterana Domovinskog rata), the Association of Disabled Croat Soldiers of the Patriotic War (Hrvatski vojni invalidi Domovinskog rata, HVIDRA) and the Association of the Families of Croat Defenders that Died or Disappeared during the Patriotic War (Udruga obitelji hrvatskih branitelja poginulih i nestalih u Domovinskom ratu). By contrast, the Organisation of Combatants of the Republika Srpska intends to represent the different segments of the Serb combatant population, despite the fact that there are small independent associations.

10. The results of the opinion poll completed within the framework of the study Local Level Institutions and Social Capital suggest that the associations of the first kind have a more important base within the population. For example, 4.4 per cent of the people interviewed (8.4 per cent of the men) declared that they were members of a veterans' association, and 3.7 per cent of the people 
interviewed (7.3 per cent of the veterans) declared that they had sought help from a veterans' association during the past year (World Bank 2002: 83-101; 165-166).

11. Personal notes, July 2003.

12. 24,000 of which were from the Federation Army (Vojska Federacije -VF), created in 1997 through a merging of the ARBiH and the $\mathrm{HVO}$, but comprising three Bosniak army brigades and one Croat army brigade.

13. Press release cited in Oslobođenje, 3 March 2002.

14. Press release cited in Oslobođenje, 4 March 2002.

15. For an example of a non-governmental organisation that has attempted to develop a specific activity aimed at the former combatants, see Fischer 2006.

\section{References}

ANDJELIC, N. 2003. Bosnia-Herzegovina: The End of a Legacy, London: Frank Cass.

ANDREAS, P. 2004. "The Clandestine Economy of War and Peace in Bosnia", International Studies Quarterly, 48(1), 29-51.

BAŠIĆ, N., 2002. "Jeder Tag war 'Allgemeine Volksverteidigung' (ONO). Zur militaristischen Kultur und Gewalterziehung im sozialistischen Jugoslawien (1945-1990)", Jahrbuch für Geschichte und Kultur Südosteuropas, 4, 69-90.

BAŠIĆ, N. 2004. Krieg als Abenteuer. Feindbilder und Gewalt aus der Perspektive exjugoslawischer Soldaten 1991-1995, Giessen: Psychosozial-Verlag.

Bougarel, X. 1996. Bosnie: anatomie d'un conflit, Paris: La Découverte.

CERIĆ, M. 2002. “Obraćanje Reisu-1-uleme u Begovoj džamiji”, Preporod, 33(1), 7.

ČOlOviĆ, I. 2005. Le bordel des guerriers. Folklore, politique et guerre, Münster: LIT Verlag.

Dimitrijević, B. B., 2001. Militarism and the Creation of Social Identities since 1945: A Comparative Study on Cases of Yugoslavia and Bulgaria, Sofia: Centre for Advanced Studies.

FISCHER, M. 2006. "Confronting the Past and Involving War Veterans for Peace Activities by the 'Center for Non-Violent Action' in Sarajevo and Belgrade", in: Martina Fischer (ed.), Peacebuilding and Civil Society in Bosnia-Herzegovina - Ten Years after Dayton, Münster: LIT Verlag, 387-416.

Gow, J. 1992. Legitimacy and the Military: The Yugoslav Crisis, London: Pinter. 
Gow, J. 2003. The Serbian Project and its Adversaries: A Strategy of War Crimes, Montréal: Mc Gill-Queen's University Press.

GREgSON, K. 2000. Veterans' Programs in Bosnia-Herzegovina, Sarajevo: The World Bank.

HADŽić, H. 1999, "Humano preseljenje", Dani, 93, available online at http://www.bhdani.com.

HADŽIĆ, M. 2004. The Yugoslav People's Agony: The Role of the Yugoslav People's Army, Aldershot: Ashgate.

HEINEMANN-GRÜDER A., 2003. Turning Soldiers into a Working Force: Demobilization and Reintegration in Post-Dayton Bosnia and Herzegovina, Bonn: Bonn International Center for Conversion.

HeLMS, E., 2003. "Gender Essentialisms and Women's Activism in Post-War BosniaHerzegovina", in: W. Giles et alii (eds), Feminists Under Fire: Exchanges across War Zones, Toronto: Between the Lines, 181-198.

HoAre, M. A. 2004. How Bosnia Armed: The Birth and Rise of the Bosnian Army, London: Saqi Books.

InTERnATIONAL CRISIS Group, 2001. Turning Strife to Advantage: A Blueprint to Integrate the Croats in Bosnia and Herzegovina, Sarajevo/Brussels: International Crisis Group.

LUKIĆ, R. 1986. La défense populaire yougoslave, Paris: Centre International de Recherche sur la Paix et d'Etudes Stratégiques.

MAČEK, I. 2005. "Sarajevan Soldier Story", in: P. Richards and B. Helander (eds), No Peace, No War: An Anthropology of Contemporary Armed Conflicts, Athens, $\mathrm{OH}$ : Ohio University Press, 57-76.

Milivojević, M., Allcock J., et MAURER P.1988. (eds), Yugoslavia's Security Dilemmas: Armed Forces, National Defence and Foreign Policy, Oxford: Berg.

MUSLIMOVIĆ, F. 1993. "Aktuelni problemi i zadaci na izgradnji morala, informativnog, propagandnog, političkog i vjerskog djelovanja u jedinicama ARBiH”, in: Press Centar ARBiH, Borac Armije Republike Bosne i Hercegovine, Sarajevo: Vojna biblioteka, 39-45.

OfFice OF THE High RePRESENTATIVE, 1998. BiH TV News Summary.

OMERAGić, S. 2001. "Državotvorna tijela", Ljiljan, 9(461), p. 5.

Philpott, C. 2005. "Though the Dog is Dead, the Pig Must Be Killed: Finishing the Property Restitution to Bosnia-Herzegovina's IDPs and Returnees", Journal of Refugee Studies, 18(1), $1-24$.

PURIŠEvić, F. 2000. Boračka zaštita u Federaciji Bosne i Hercegovine, Sarajevo: Institut za istraživanje zločina protiv čovječnosti i međunarodnog prava. 
REMIngton, R. A. 1978. "The Military as an Interest Group in Yugoslav Politics", in: D. R. Herspring et I. Volgyes (eds), Civil-Military Relations in Communist Systems, Boulder, CO: Westview, 181-199.

Stefansson, A. 2004. "Sarajevo Suffering: Homecoming and the Hierarchy of Homeland Hardship", in: F. Markowitz and A. Stefansson (eds), Homecomings: Unsettling Paths of Return, Lanham, MD: Lexington Books, 54-75.

StubBS, P. 1999. Displaced Promises: Forced Migration, Refuge and Return in Croatia and Bosnia-Herzegovina, Sweden: LPI.

TABEAU E. et BIJAK, J., 2005. "War-Related Deaths in the 1992-1995 Armed Conflicts in Bosnia and Herzegovina: A Critique of Previous Estimates and Recent Results", European Journal of Population, 21(2-3), 187-215.

THE WORLD BANK, 2002. Bosnia and Herzegovina: Local Level Institutions and Social Capital, Washington D.C.: The World Bank.

ŽANIĆ, I. 1998. Prevarena povijest. Guslarska estrada, kult hajduka i rat u Hrvatskoj i Bosni $i$ Hercegovini, Zagreb: Durieux. 